\title{
ФАРМАКОЛОГИЧЕСКИЙ ПРОФИЛЬ ЗАМЕЩЕННОГО ГЛИПРОЛИНА ГЗК-111, ПРЕДШЕСТВЕННИКА ЦИКЛОПРОЛИЛГЛИЦИНА
}

\author{
К.Н. Колясникова', Е.А. Кузнецова', Т.А. Гудашева', С.Б. Середенин ${ }^{2}$ \\ ${ }^{1}$ Отдел химии лекарственных средств, \\ ²Отдел фармакогенетики ФГБНУ «НИИ фармакологии имени В.В. Закусова», \\ 125315, РФ, Москва, ул. Балтийская, 8.
}

DOI: 10.19163/MedChemRussia2021-2021-188

E-mail:kszolotova@mail.ru

Цикло-пролилглицин (ЦПГ), ранее сконструированный в НИИ фармакологии имени В.В. Закусова как дипептидный топологический аналог классического ноотропа пирацетама, был обнаружен нами в мозге крыс в качестве физиологического соединения [1]. Открытие ЦПГ было подтверждено зарубежными исследователями, которые показали, что его эндогенным предшественником является $\mathrm{N}$-концевой трипептид H-Gly-Pro-Glu-OH инсулиноподобного фактора роста 1 [2]. Для ЦПГ в экспериментах in vivo были выявлены ноотропный, анксиолитический, антигипоксический, нейропротекторный, антидепрессивный и анальгетический эффекты. В экспериментах in vitro было показано, что он способен оказывать положительное модулирующее действие на глутаматные АМРА-рецепторы и усиливать синтез мозгового нейротрофического фактора (BDNF). В связи с последним нами было высказано [3, 4] предположение о его BDNF-ергическим механизме действия.

Целью данной работы было создание пролекарства, способного превращаться в ЦПГ in vivo. Нами сконструирован и синтезирован замещенный дипептид, этиловый эфир N-фенилацетилглицил-L-пролина (N-Phac-Gly-L-Pro-OEt, ГЗК-111) и изучены его фармакологические эффекты. В батарее валидированных тестов показано, что при внутрибрюшинном введении в диапазоне доз 0,1-10 мг/ кг ГЗК-111 проявляет комплекс фармакологических эффектов, характерных для ЦПГ, при этом его активность сохраняется при пероральном введении (10 и 30 мг/ кг). Также показано превращение ГЗК-111 в циклопролилглицин in vitro и in vivo.

Таким образом, полученный линейный замещенный глипролин ГЗК-111 может рассматриваться как терапевтически потенциальный для комплексного лечения психиатрических патологий, включающих тревожные, депрессивные расстройства и нарушения когнитивных функций.

Работа выполнена при поддержке РФФИ (проект № 20-015-00102).

\section{Литература}

[1] T.A. Gudasheva, S.S Boyko, V.Kh Akparov et al., FEBS Letters, 1996, 391(1-2), 149-152.

[2] J. Guan, P. Gluckman, P. Yang, et al., Scientific reports, 2015, 4, 4388.

[3] Т.А. Гудашева, В.В. Григорьев, К.Н. Колясникова и др., Доклады академии наук, 2016, 471(1), 106-108.

[4] Т.А. Гудашева, К.Н. Колясникова, Т.А. Антипова, и др., Доклады Академии наук, 2016, 469(4), 492-495. 